\title{
Mechanism of Change in the
}

\section{Excretion of Sodium Per Nephron}

\section{When Renal Mass Is Reduced}

\author{
John P. Hayslett, Michael Kashgarian, and \\ FrankLIN H. EPSTEIN
}

From the Departments of Internal Medicine and Pathology, Yale University School of Medicine, New Haven, Connecticut 06525

\begin{abstract}
A BSTRACT As the population of nephrons is reduced, sodium excretion per nephron must increase if sodium balance is to be maintained. The mechanism of this adjustment was studied in rats in which $50 \%$ and approximately $85 \%$ of renal tissue was excised. Although glomerular filtration per remaining nephron rose after uninephrectomy, it did not rise further when more renal tissue was removed, even though sodium excretion per nephron mounted. Hyperfiltration does not, therefore, account for the stepwise increase in sodium excretion per nephron with progressive renal ablation. Proximal tubular absorption, estimated by reabsorption half-time, was unchanged by renal insufficiency, indicating that "third factor" did not produce the observed changes in sodium excretion per nephron. It seems likely that the earliest adjustments in sodium excretion in renal failure take place in the distal tubules of healthy nephrons, and that they are conditioned by changes in the osmotic load per nephron.
\end{abstract}

\section{INTRODUCTION}

As the population of nephrons is reduced by renal disease or by ablation of renal tissue, sodium excretion per nephron must increase to maintain normal sodium balance. At least three possible mechanisms have been proposed to explain this adjustment. First, it is clear that when the number of functioning nephrons is reduced, filtration through the remaining nephrons is increased (1). Increased excretion of sodium per nephron might therefore result from an augmented filtered load of sodium, part of which escapes reabsorption. Second, as renal mass is reduced, there is necessarily an increase in

Received for publication 30 September 1968 and in revised form 21 December 1968. the excretion of solutes per nephron which might be responsible for the forced excretion of sodium through the mechanism of osmotic diuresis. Thirdly, it has been suggested that the adjustment in sodium excretion is related to expansion of body fluids via a natriuretic "third factor" which decreases sodium reabsorption in the proximal tubule (2).

An attempt was made in the present experiments to clarify this problem by studying renal function with micropuncture techniques in rats in which renal tissue was progressively ablated. The results indicate that neither hyperfiltration nor diminished proximal tubular absorption accounts for the increase in sodium excretion per nephron in renal failure.

\section{METHODS}

Experiments were performed upon three groups of male Sprague-Dawley rats. All animals had free access to tap water and regular Purina chow containing approximately $100 \mathrm{mEq} \mathrm{Na} / \mathrm{kg}$ of diet, until anaesthesia was induced. Group A consisted of normal rats, weighing $386 \pm 5 \mathrm{~g}$ (mean ISE) which served as the control group. Group B rats had undergone uninephrectomy. The right kidney was removed under ether anesthesia. Studies were performed 2-3 wk aftr surgery when compensatory hypertrophy of the remaining kidney had become stable. The average weight of these rats was $375 \pm 6 \mathrm{~g}$. The blood urea nitrogen in group $A$ and $B$ rats was $25.7 \pm 1.2$ and $27.0 \pm 0.8 \mathrm{mg} / 100 \mathrm{ml}$, respectively. Data from these two groups have been published in part previously (3). Group $\mathrm{C}$ rats were azotemic (BUN $52.1 \pm 2.8 \mathrm{mg} / 100 \mathrm{ml}$ ) after ablation of approximately $85 \%$ of renal tissue. Reduction of nephron mass was accomplished in two stages before study. In the first stage the upper and lower poles of the left kidney were removed under ether anesthesia. A mattress suture was placed around each pole and tightened until the pole became ischemic. Renal tissue distal to the tie was then excised with a razor blade. 4-5 days after this procedure, the right kidney was removed. Experiments were performed 5-40 days afterwards. Most 
of the animals in this group failed to gain weight normally after surgery and consequently they weighed less than rats in the other groups, averaging $293 \pm 17 \mathrm{~g}$.

When micropuncture experiments were performed, anesthesia was induced with Inactin (Promonta, Hamburg, Germany), $160 \mathrm{mg} / \mathrm{kg}$ intraperitoneally, a tracheotomy was performed and the bladder was cannulated with polyethylene tubing. The left kidney was exposed, the capsule stripped, and the kidney immobilized in a plastic cup (4). During surgery, isotonic saline equal to $1 \%$ of the body weight was infused intravenously to compensate for losses of extracellular fluid. A sustaining infusion of isotonic saline at $1.2 \mathrm{ml} / \mathrm{hr}$ was continued during the entire experiment.

Glomerular filtration rate (GFR) was measured using inulin-methoxy-'H (New England Nuclear Corp., Boston, Mass.). After a priming dose of $75 \mu \mathrm{c}$, inulin ${ }^{3} \mathrm{H}$ was infused at a rate of $75 \mu \mathrm{c} / \mathrm{hr}$. The filtration rate in indivicual nephrons was measured by collecting samples of proximal tubular fluid during timed intervals of approximately 2 min. The radioactivity of samples in Bray's solution was determined in a Tri-Carb liquid scintillation spectrometer. Counts were corrected for quenching using a ${ }^{8} \mathrm{H}$ internal standard. Urine was collected at intervals of approximately $30 \mathrm{~min}$ and samples of blood were taken from the tail before and after each collection. The volumes of samples of urine and plasma were measured with calibrated glass micropipettes.

Serum and urine values for sodium were determined on an internal standard flame photometer.

The half-time of reabsorption ( $\left.t_{3}\right)$ of isotonic saline in split-droplet microperfusions of single proximal tubules was measured by sequence photomicrography as described by Gertz (5).

\section{RESULTS}

Glomerular filtration rate per animal and per nephron after reduction of renal mass (Table $I$ ). The rate of glomerular filtration (GFR) in rats of group $A$ with two normal kidneys, was $820 \pm 40 \mu \mathrm{l} / \mathrm{min}$ per $100 \mathrm{~g}$ body weight (mean $\pm \mathrm{SE}$ ). The GFR in rats of group $\mathrm{B}$, with a single kidney, was $720 \pm 30 \mu \mathrm{l} / \mathrm{min}$ per $100 \mathrm{~g}$ body weight, or $85 \%$ of normal. In group $\mathrm{C}$ the total glomerular filtration rate of the kidney remnant was reduced to $190 \pm 36 \mu \mathrm{l} / \mathrm{min}$ per $100 \mathrm{~g}$ body weight, which was only $23 \%$ of the normal rate.

\section{TABLE I}

Relationship between Glomerular Filtration Rate (GFR) and Renal Mass*

\begin{tabular}{lccc}
\hline & $\begin{array}{c}\text { Group A, } \\
\text { control }\end{array}$ & $\begin{array}{c}\text { Group B, } \\
50 \% \\
\text { nephrectomy }\end{array}$ & $\begin{array}{c}\text { Group C, } \\
85 \% \\
\text { nephrectomy }\end{array}$ \\
\hline $\begin{array}{l}\text { GFR per rat, } \\
\mu l / \text { min per } 100 \mathrm{gm} \\
\text { body wt }\end{array}$ & $\begin{array}{c}820.0 \pm 40 \\
(\mathrm{n}=52)\end{array}$ & $\begin{array}{c}720.0 \pm 30 \\
(\mathrm{n}=44)\end{array}$ & $\begin{array}{c}190.0 \pm 36 \\
(\mathrm{n}=21)\end{array}$ \\
$\begin{array}{l}\text { GFR per nephron, } \\
\text { nl/min }\end{array}$ & $\begin{array}{l}45.2 \pm 3.5 \\
(\mathrm{n}=27)\end{array}$ & $\begin{array}{l}78.8 \pm 9.2 \\
(\mathrm{n}=17)\end{array}$ & $\begin{array}{l}74.9 \pm 5.0 \\
(\mathrm{n}=28)\end{array}$ \\
\hline
\end{tabular}

* Values represent means \pm SE. $n$, number of observations.

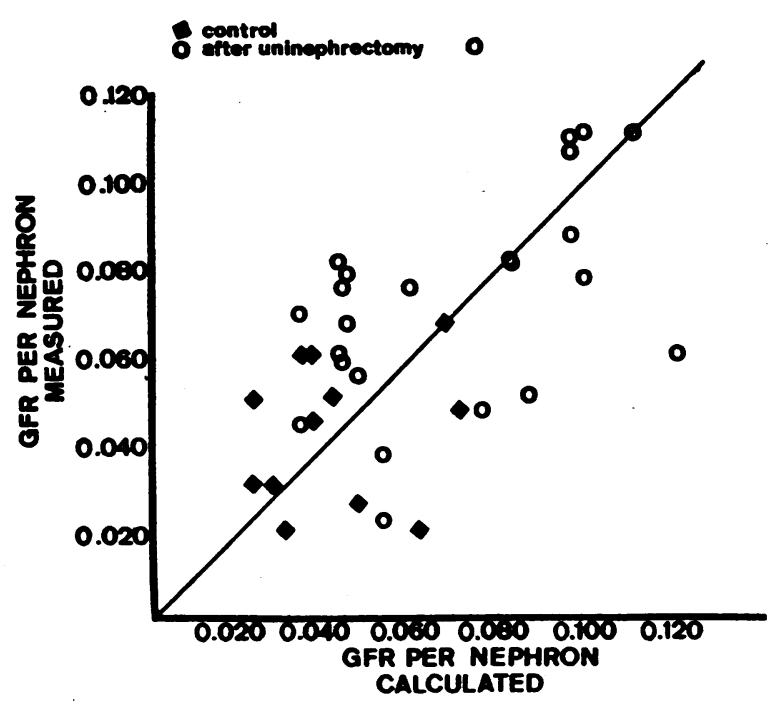

FIGURE 1 Correlation between inulin clearance (GFR) per nephron calculated from the GFR per kidney, and GFR per nephron measured at the same time in an individual surface nephron by micropuncture. The heavy diagonal line indicates exact correspondence. Units are microliters per min. Points include data from reference 3 .

In normal animals (group A) the inulin clearance in surface nephrons was $45 \pm 3.7 \mathrm{nl} / \mathrm{min}$ per nephron. After removal of one kidney, filtration in individual nephrons of rats in group B increased $76 \%$ to $79 \pm 9.2$ $\mathrm{nl} / \mathrm{min}$ per nephron. An important finding was that in group C rats, in which roughly $85 \%$ of kidney mass had been removed (see below), GFR in the remaining individual surface nephrons did not increase proportionately. The average inulin clearance in rats of group $\mathrm{C}$ was $75 \pm 5.0 \mathrm{nl} / \mathrm{min}$ per nephron. There was no significant difference between the filtration rate of surface nephrons in rats with only one kidney removed (group B) and rats in which the remaining renal mass had been further and markedly reduced (group C).

A critical question in these experiments was the extent to which glomerular filtration measured in individual surface nephrons reflected changes in all nephrons of the kidney. An approximate answer can be obtained by measuring the inulin clearance of a single nephron at micropuncture, and comparing it with the GFR per nephron calculated by dividing the GFR of the kidney as a whole by 27,000 , the approximate number of nephrons in a rat kidney (6). Fig. 1 illustrates that both in normal rats and after compensatory hypertrophy had been stimulated by removal of one kidney, GFR in surface nephrons is roughly proportional to glomerular filtration rate in the kidney as a whole (3). A similar proportionality is also reported (7) when GFR is reduced by applying a clamp to the renal artery. The number of functioning nephron units remaining after 
TABLE II

Filtration and Excretion of Sodium after Reduction of Renal Mass*

\begin{tabular}{|c|c|c|c|c|}
\hline & $\begin{array}{l}\text { Sodium filtered } \\
\text { per rat }\end{array}$ & $\begin{array}{l}\text { UNKV per } \\
\text { GFR of rat }\end{array}$ & $\begin{array}{l}\text { Sodium filtered } \\
\text { per nephron }\end{array}$ & $\begin{array}{l}\mathrm{UNaV}_{\mathrm{Na}} \text { per } \\
\text { nephronf }\end{array}$ \\
\hline & $m E q / \min$ & $n E q / \mu l$ & $n E q / \min$ & $n E q / \min$ \\
\hline Group A, control & $\begin{array}{c}0.44 \pm 0.02 \\
(\mathrm{n}=52)\end{array}$ & $\begin{array}{c}0.17 \pm 0.02 \\
(n=52)\end{array}$ & $\begin{array}{l}6.3 \pm 0.5 \\
(n=27)\end{array}$ & 0.008 \\
\hline $\begin{array}{l}\text { Group B, } \\
50 \% \text { nephrectomy }\end{array}$ & $\begin{array}{c}0.38 \pm 0.02 \\
(n=44)\end{array}$ & $\begin{array}{c}0.26 \pm 0.05 \\
(n=44)\end{array}$ & $\begin{array}{l}11.1 \pm 1.2 \\
(n=17)\end{array}$ & 0.021 \\
\hline $\begin{array}{l}\text { Group C, } \\
\quad 85 \% \text { nephrectomy }\end{array}$ & $\begin{array}{c}0.08 \pm 0.015 \\
(\mathrm{n}=21)\end{array}$ & $\begin{array}{c}0.66 \pm 0.14 \\
(\mathrm{n}=19)\end{array}$ & $\begin{array}{l}10.5 \pm 0.7 \\
(\mathrm{n}=28)\end{array}$ & 0.049 \\
\hline
\end{tabular}

* Values represent means \pm SE. $n$, number of observations.

$\ddagger$ Calculated as $\mathrm{U}_{\mathrm{Na}} \mathrm{V}$ ( $\mathrm{nEq} / \mathrm{min}$ ) divided by number of functioning nephrons. Since number of functioning nephrons equals (GFR $\mu \mathrm{l} / \mathrm{min}$ per rat)/(GFR $\mu \mathrm{l} / \mathrm{min}$ per nephron), $\mathrm{U}_{\mathrm{Na}} \mathrm{V}$ per nephron equals $\left(\mathrm{U}_{\mathrm{Na}} \mathrm{V} \mathrm{nEq} / \mathrm{min}\right.$ per rat)/(number of nephrons).

partial nephrectomy or in the presence of renal disease is conventionally estimated from the over-all glomerular filtration rate. This method is clearly inaccurate because of the adaptive increase in GFR that occurs when renal mass is reduced. In the experiments of group $C$, the GFR of the kidney remnant, divided by the GFR of surface nephrons, averaged $7412,14 \%$ of the normal number of nephrons per two kidneys. It seems fair to conclude that roughly $85 \%$ of renal mass was removed by the two-stage operation.

Filtration and excretion of sodium after reduction of kidney mass (Table II, Fig. 2). As renal mass was progressively reduced by nephrectomy, the proportion of filtered sodium excreted in the urine simultaneously increased. Sodium excretion was $0.17 \mathrm{nEq} / \mu \mathrm{l}$ of $\mathrm{GFR}$ in intact rats (group A), 0.26 after unilateral nephrectomy (group B), and 0.66 in the rats of group C, after still more renal tissue had been removed. The calculated excretion of sodium per nephron increased from 0.008 $\mathrm{nEq} / \mathrm{min}$ to $0.021 \mathrm{nEq} / \mathrm{min}$ in group $\mathrm{B}$ and to 0.049

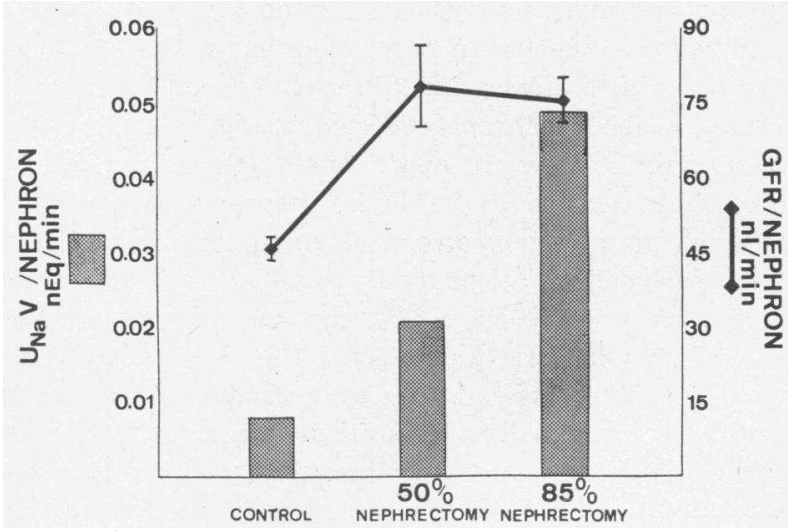

FIGURE 2 Excretion of sodium $\left(\mathrm{U}_{\mathrm{Na}} \mathrm{V}\right)$ per nephron and glomerular filtration rate (GFR) per nephron, measured in individual surface nephrons of control and experimental rats.
$\mathrm{nEq} / \mathrm{min}$ in group C. On the other hand, the quantity of sodium filtered per nephron increased by $76 \%$ in group B but did not rise further in rats in group $C$. The progressive increase in sodium excretion per nephron observed in these animals cannot therefore be accounted for by an increase in nephron filtration rate.

Intrinsic reabsorption in proximal tubular segments after reduction of renal mass (Table III). The intrinsic reabsorptive capacity of proximal tubular segments was determined using the half-reabsorption time ( $\left.t_{1}\right)$ of Gertz. The $t_{1}$ was the same in rats with partial nephrectomy as in control animals. The mean $t \frac{1}{3}$ was $9.3 \pm 0.2 \mathrm{sec}$ (mean $\pm \mathrm{SE}$ ) in group $\mathrm{A}, 9.3 \pm 0.2 \mathrm{sec}$ in group $\mathrm{B}$, and $8.9 \pm 0.3 \mathrm{sec}$ in group $\mathrm{C}$. In contrast, the half-reabsorption time is readily prolonged in rats in which the extracellular fluid is expanded with saline (8). As indicated in Table III, the $t_{3}$ in rats infused with a volume of isotonic saline equal to $10 \%$ of their body weight was slowed to $11.9 \pm 0.5 \mathrm{sec}(P<0.001)$.

\section{DISCUSSION}

As the population of surviving nephrons is reduced, either by disease or surgical ablation, the quantity of sodium excreted per nephron progressively increases.

TABLE III

Half-Volume Reabsorption Time $\left(t_{\xi}\right)$ in the Proximal Tubule*

\begin{tabular}{lcccc}
\hline & $\begin{array}{c}\text { Group A, } \\
\text { control }\end{array}$ & $\begin{array}{c}\text { Group B, } \\
50 \% \\
\text { nephrectomy }\end{array}$ & $\begin{array}{c}\text { Group C, } \\
85 \% \\
\text { nephrectomy }\end{array}$ & $\begin{array}{c}\text { Saline } \\
\text { loaded }\end{array}$ \\
\hline $\mathrm{t}_{\frac{1}{3}}$ sec & $9.3 \pm 0.2$ & $9.3 \pm 0.2$ & $8.9 \pm 0.3$ & $11.9 \pm 0.4$ \\
& $(\mathrm{n}=48)$ & $(\mathrm{n}=63)$ & $(\mathrm{n}=43)$ & $(\mathrm{n}=30)$ \\
$P$ value & & $\mathrm{NS}$ & $\mathrm{NS}$ & $<0.001$
\end{tabular}

*Values represent means \pm SE. $n$, number of observations. 
In this way water and sodium balance are maintained despite a diminishing glomerular filtration rate when intake of salt and water is unaltered. Thus, in the present experiments, when the number of nephrons was halved by uninephrectomy, the quantity of sodium excreted per nephron increased more than twofold, and when renal mass was reduced even further, sodium excretion per nephron increased in rough proportion.

These changes have been ascribed in the past to the increase in filtration rate of individual nephrons which occurs as renal mass contracts. Such an increase would result in a greater delivery of solutes to the renal tubule, and part of the increased solute load would presumably escape reabsorption. The inulin clearance of individual surface nephrons increased by $65-75 \%$ after partial nephrectomy in the present experiments. This is in general agreement with other reports. For example, Bank and Aynedjian found that nephron GFR rose about $60 \%$ above normal in rats with bilateral pyelonephritis that had produced a $43 \%$ reduction in total filtration rate (9). Bricker, Klahr, and Rieselbach found that the GFR increased by $60 \%$ in a single diseased kidney of dogs when the contralateral control kidney was removed (1).

It seems unlikely, however, that changes in filtration rate are primarily responsible for the modulation of sodium excretion. As shown in Figure 2, nephron GFR apparently attains a maximum of approximately $75 \mathrm{nl} /$ min after $50 \%$ of nephrons are removed. Nevertheless, sodium excretion per nephron increases considerably with further ablation of renal tissue even though filtration remains the same.

It has been suggested recently by Schultze and coworkers that the increased sodium excretion per nephron in uremia results from the action of the same "third factor" that subserves volume regulation during acute volume expansion (2). This implies diminished absorption in the proximal tubule. The hypothesis was strengthened by a recent report of a humoral factor recovered from the serum of uremic patients, that prolonged proximal reabsorptive half-time in single proximal tubules of the rat kidney (10). In experimental forms of renal injury or ablation in the rat, however, there is little evidence for a decrease in proximal reabsorption. Proximal TF/P ratios for inulin are unchanged by uninephrectomy (3) or by experimental pyelonephritis $(9,11)$. The present experiments show clearly that when renal mass is reduced, sodium excretion per nephron is greatly increased at the same time that reabsorption in the proximal tubule, as measured by the shrinking-drop technique, is unaltered.

It is interesting to compare these experiments in rats with those in which saline infusions caused comparable increases in sodium excretion. The animals with $85 \%$ nephrectomy excreted $0.5 \%$ of their filtered sodium. When normal rats were infused with saline so as to increase sodium excretion to $0.5 \%$ of the filtered load, reabsorptive half-time of the shrinking drop was prolonged from $8.5 \pm 0.2$ to $11.9 \pm 0.5 \mathrm{sec}$ (8). Since prolongation of reabsorptive half-time is the hallmark of the "third factor(s)" mediating saline diuresis, it appears that these factors may not be responsible or necessary for the adjustment in sodium excretion per nephron that characterizes renal failure. Changes in proximal tubular absorption may of course ocur in advanced uremia, especially when the body is overloaded with salt and water, but are not necessarily a feature of the early accommodations to renal insufficiency.

The present findings strongly suggest that as renal mass is reduced, sodium excretion is kept constant by a decrease in the reabsorption of sodium in the distal tubule. This conclusion is supported by Bank and Aynedjian, who found that distal TF/P ratios for inulin were depressed in experimental pyelonephritis, though there was no change in inulin $\mathrm{TF} / \mathrm{P}$ ratio in the proximal tubule (12). We suggest that the primary reason for this is the increased osmotic load of solutes, and especially urea, per nephron. The notion that urine formed during renal insufficiency results from osmotic diuresis through a few remaining normal nephrons is a familiar one, well articulated by Platt (13). While massive urea loads can decrease reabsorption in the proximal tubule (14), mild urea diuresis is likely to retard absorption chiefly in the lower reaches of the nephron since it is here that the concentration of urea rises highest and it is here as well that the tubular epithelium is least permeable to the back-diffusion of urea (15). The earliest effect of urea diuresis, evident from the data of Biber and coworkers (14), is to decrease the distal absorption of sodium. Presumably, this effect was operative in the partially nephrectomized rats of our experiments.

Although mild urea diuresis might account for an increased sodium excretion per nephron in uremia, it does not explain the delicate adaptive adjustment of the kidney remnant that enables the partially nephrectomized animal to maintain sodium balance. To do this it is necessary to postulate the intervention of additional factors conditioning sodium excretion, which exert their chief effect in the distal tubule and collecting duct. One of these may be aldosterone. It is clear that mineralocorticoids can greatly modify the excretion of sodium during urea diuresis $(16,17)$, and it is of special interest that the secretion of aldosterone has been reported to be elevated in uremic patients $(18,19)$. It seems likely that when the mass of the kidneys is reduced, final adjustments in sodium reabsorption are made chiefly in the distal tubules and collecting ducts 
to modify the salt-wasting effect of osmotic diuresis on behalf of the concentration and volume of body fluids.

\section{ACKNOWLEDGMENTS}

The authors are grateful to Helen Gilbert, Dorothy Smith, and Nadia Myketey for their expert technical assistance.

This work was supported by research grants from the U. S. Public Health Service (AM 07369 and HE 00834) and the American and Connecticut Heart Associations. Dr. Hayslett was supported by Training Grant TIAM 5015 from the U. S. Public Health Service. Dr. Kashgarian received U. S. Public Health Service Research Career Development Award K3-HE 13683. Dr. Epstein received U. S. Public Health Service Research Career Award K6-AM21578.

\section{REFERENCES}

1. Bricker, N. S., S. Klahr, and R. E. Rieselbach. 1964. The functional adaptation of the diseased kidney. I. Glomerular filtration rate. J. Clin. Invest. 43: 1915.

2. Schultze, R. G., E. Slatopolsky, B. Tall, W. Walker, M. Levy, and N. S. Bricker. 1966. The regulation of sodium excretion in uremia: a new dimension in the characterization of "third factor." Trans. Ass. Amer. Physicians Philadelphia. 79: 322.

3. Hayslett, J. P., M. Kashgarian, and F. H. Epstein. 1968. Functional correlates of compensatory renal hypertrophy. J. Clin. Invest. 47: 774.

4. Wirz, H. 1956. Der osmotische Druck in den corticalen Tubuli der Rattenniere. Helv. Physiol. Pharmacol. Acta. $14: 353$.

5. Gertz, K. H. 1963. Transtubulare Natriumchloridflüsse und Permeabilitat für Nichtelektrolyte im proximalen und distalen Konvolut der Ratteniere. Pfiügers Arch. Gesamte Physiol. Menschen Tiere. 276: 336.

6. Morrison, A. B., and R. M. Howard. 1966. The functional capacity of hypertrophied nephrons. Effect of partial nephrectomy on the clearance of inulin and PAH in the rat. J. Exp. Med. 123: 829.

7. Windhager, E. E. 1968. Glomerular-tubular balance of salt and water. Physiologist. 11: 103.
8. Hayslett, J. P., M. Kashgarian, and F. H. Epstein. 1967. Changes in proximal and distal tubular reabsorption produced by rapid expansion of extracellular fluid. J. Clin. Invest. 46: 1254.

9. Bank, N., and H. S. Aynedjian. 1966. Individual nephron function in experimental bilateral pyelonephritis. I. Glomerular filtration rate and proximal tubular sodium, potassium and water reabsorption. J. Lab. Clin. Med. 68: 713 .

10. Kurtzman, N. A., M. G. White, A. R. Hull, F. C. Rector, Jr., and D. W. Seldin. 1968. The significance of natriuretic hormone in renal failure. Clin. Res. 16: 91. (Abstr.)

11. Lubowitz, H., M. L. Purkerson, and N. S. Bricker. 1966. Investigation of single nephrons in the chronically diseased (pyelonephritic) kidney of the rat using micropuncture techniques. Nephron. 3: 73.

12. Bank, N., and H. S. Aynedjian. 1966. Individual nephron function in experimental bilateral pyelonephritis. II. Distal tubular sodium and water reabsorption and the concentrating defect. J. Lab. Clin. Med. 68: 728.

13. Platt, R. 1952. Structural and functional adaptation in renal failure. Brit. Med. J. 1: 1372.

14. Biber, T. U. L., M. Mylle, W. E. Lassiter, and C. W. Gottschalk. 1965. Micropuncture study of water reabsorption and PAH secretion in urea diuresis in rats. Proc. Soc. Exp. Biol. Med. 119: 871.

15. Carrasquer, G., S. Solomon, and H. Sonnenberg. 1967. Evidence of restricted permeability to urea in rat distal tubule. Proc. Soc. Exp. Biol. Med. 125: 828.

16. Platts, M. M. 1966. Electrolyte excretion in uremia. Clin. Sci. 30: 453.

17. Gonick, H. C., J. W. Coburn, M. E. Rubini, M. H. Maxwell, and C. R. Kleeman. 1964. Studies of experimental renal failure in dogs. II. Effect of five-sixths nephrectomy on sodium-conserving ability of residual nephrons. J. Lab. Clin. Med. 64: 269.

18. Cope, C. L., and J. Pearson. 1963. Aldosterone secretion in severe renal failure. Clin. Sci. 25: 331.

19. Gold, E. M., C. R. Kleeman, S. Ling, M. Yawata, and M. Maxwell. 1965. Sustained aldosterone secretion in chronic renal failure. Clin. Res. 13: 135. (Abstr.) 